\title{
Optimal Bidding strategy in South Region Day-ahead Market Model using New Aggregated Demand Model and Hybrid Technique
}

\author{
V. Madhu Sudana Reddy \\ Research Schloar, \\ Dept. of E.E.E., \\ J.N.T.U.H, \\ Hyderabad, India
}

\author{
B. Subramanyam, $\mathrm{PhD}$ \\ Professor, \\ Dept. of E.E.E., \\ K.L.University, \\ Vijayawada, India
}

\author{
M. Surya Kalavathi, PhD \\ Professor, \\ Dept. of E.E.E. \\ J.N.T.U.H. \\ Hyderabad, India.
}

\begin{abstract}
In this paper a half breed calculation (ABC_PSO) comprising of Artificial Bee Colony (ABC) and Particle Swarm Optimization (PSO) in light of demonstrating for the ideal offering systems in an aggressive power force business sector is proposed. We set forward a novel enhanced strategy which enhances the Profit of the suppliers. In the aforementioned technique ideal using so as to offer parameters are controlled the two periods of the Artificial Bee Colony (ABC). From the streamlined parameters the definite arrangement is anticipated by utilizing third phase of the $\mathrm{ABC}$ calculation i.e scout honey bee. Here, the honey bee's populace speed and the position vector are enhanced by utilizing the method of PSO rather than Scout honey bee, to locate the precise offering parameters. The Indian Energy Exchange (IEX) hourly based burden request dataset is utilized for using so as to foresee the heap Artificial Neural Network (ANN) system. At long last the proposed system is executed in the MATLAB/simulink stage and viability is investigated by utilizing the correlation of distinctive procedures like Artificial Bee Colony (ABC) calculation, Particle Swarm Optimization (PSO) calculation, ABC_PSO. The aftereffects of examination exhibited the prevalence of the proposed approach and affirm its capability to take care of the issue.
\end{abstract}

\section{Keywords}

ABC, PSO, ANN, optimal bidding, electricity power market

\section{INTRODUCTION}

IN MANY nations everywhere throughout the world, the force business is moving towards a focused system and a business sector environment is supplanting the customary brought together operation approach. The fundamental goal of a power business sector is to diminish the expense of power through rivalry. The business sector environment normally comprises of a pool and a story to complete reciprocal contracts. Satisfactory new programming apparatuses are expected to bolster new exercises in the pool, for example, advancement based era schedulers and value offering instruments. The pool, or power trade (PX), is an e-business commercial center where producing organizations (GENCOs) submit supplier offers and their comparing costs and purchaser organizations (CONCOs) do likewise with interest offers. The business sector administrator (MO) utilizes a business sector clearing device to clear the business sector at consistently and these outcomes in a business sector clearing value (MCP) and the arrangement of acknowledged generation and utilization offers. From a pool point of view, a suitable business sector clearing device is a twofold closeout system [1]-[3]. Hourly barters are performed each one in turn and repair heuristics are utilized to make comes about in fact possible. Hourly conformity markets are likewise used to consider deviations and to repair infeasibilities. In this paper we proposed two systems for estimating burden utilizes Artificial Neural Network (ANN) and to streamline target capacity by utilizing ABC, PSO and ABC_PSO

\section{PROBLEM FORMULATION}

The power market structure containing number of sellers and large consumers are applying bidding model to maximize their profits and to minimize the associated risks. Instead of this the demand of the system must be satisfied. Suppliers should apply bid slightly higher values at their optimum production cost, but it depends on the market behaviors, competitors and technical constraints. In this proposed system

consider $p_{i}$ number of generators and $q$ number of large consumers, ISO controls the demand side bidding of the participants in the network. The sellers require bidding of a linear non decreasing supply curve and the large consumers should have non increasing demand curve respectively to a power exchange (PX). The optimum linear sellers curve and the linear large consumers curve are described in the following equations (1) and (2) respectively.

The following is a sellers curve

$$
G_{i}\left(P_{i}\right)=a_{i}+b_{i} P_{i}
$$

For large consumers linear demand curve is

$$
\begin{aligned}
& W_{j}\left(L_{j}\right)=c_{j}-d_{j} L_{j} \\
& \text { Where, } i=1,2 \mathrm{~K} p \text { and } j=1,2 \ldots q \\
& P_{i} \text { is the real power output of the } i^{\text {th }} \text { generation unit, } a_{i} \\
& \text { and } b_{i} \text { is the bidding coefficients of the } i^{\text {th }} \text { seller, } c_{j} \text { and } \\
& d_{j} \text { is the bidding coefficients of the } j^{\text {th }} \text { large consumer } \\
& \text { and } L_{j} \text { is an active power load of the } j^{\text {th }} \text { large consumer, }
\end{aligned}
$$
while $a_{i}, b_{i}, c_{j} d_{j}$ are positive values. The power exchange system mainly considers the generation, demand, dispatch and schedule that meet the constraints to maximize profits. In addition, when the power generation sellers and large consumers bid linear supply and demand functions of the network constraints are ignored, and maximizing payoff leads to a uniform market clearing price for all suppliers and 
consumers. Thus when only the constraints like, generation output, load flow and customer demand are considered, PX determines the set of generation outputs $P=\left(P_{1}, P_{2}, \mathrm{~K}, . . P_{p}\right)^{T}$ and a set of large consumer's demands $L=\left(L_{1}, L_{2}, \mathrm{~K}, . . L_{q}\right)^{T}$ solving equations (3) to (7). by

$$
\begin{aligned}
& a_{i}+b_{i} P_{i}=R \\
& c_{j}-d_{j}=R \\
& \sum_{i=1}^{p} P_{i}=Q(R)+\sum_{j=1}^{q} L_{j}
\end{aligned}
$$

Where, $P_{i}$ is the active power output of the $i^{t h}$ generation unit, $Q(R)$ is the aggregate a pool load forecast, $L_{j}$ is an active power load of the $j^{\text {th }}$ large consumer. The consideration of the constraints is given below,

$$
\begin{aligned}
& P_{\min , i} \leq P_{i} \leq P_{\max , i} \quad i=1,2,3 \ldots P_{(6)} \\
& L_{\min , j} \leq L_{j} \leq L_{\max , j} \quad j=1,2,3 \ldots q_{(7)}
\end{aligned}
$$

$P_{\min , i} \& P_{\max , i}$ are the generation output limits of the $i_{\text {seller, and }}^{\text {th }} L_{\min , j} \& L_{\max , j}$ are the demand limits of the $j^{\text {th }}$ large consumer. The value of $\mathrm{Q}(\mathrm{R})$ is given by solving equations (3) to (5).

$$
Q(R)=Q_{o}-K R
$$

Where Qo is constant number and $\mathrm{K}$ is a coefficient denoting price elasticity of the aggregate demand. If pool demand is largely inelastic, then $\mathrm{k}=0$.

$$
\begin{gathered}
P_{i}=\frac{R-a_{i}}{b_{i} \quad i=1,2,3 \ldots p} \\
L_{j}=\frac{c_{j}-R}{b_{j}} \quad i=1,2,3 \ldots q \\
R=\frac{Q_{o}+\sum_{i=1}^{p} \frac{a_{i}}{b_{i}}+\sum_{j=1}^{q} \frac{c_{j}}{d}}{K+\sum_{i=1}^{p} \frac{1}{b_{i}}+\sum_{j=1}^{q} \frac{1}{d}}
\end{gathered}
$$

Where, $\boldsymbol{R}$ is the market clearing price, the above equations (9), (10) and (11) violates the generation and consumer demand limits (6) and (7), it must be customized to accommodate these constraints. In a sealed bid auction based power market, there is no need to solve the equations (6) and (7). The objective function ' $F$ ' is used for the Artificial Bee Colony Algorithm; here referred to as "ABC", depending on the objective function the best value can be calculated. The hybrid technique using Particle Swarm Optimization, here referred to as "PSO", at the third step of the ABC algorithm. The large consumer demand has been given by the Neural Network, here referred to as "NN". It is trained with the datasets of the generating units on the basis of the bus system. The detailed explanation of the proposed hybrid technique is given in the following section

The maximization of the objective function for building a bidding strategy can be described by the following equation.

$$
\operatorname{Max} F=F\left(a_{i}, b_{i}\right)=R P_{i}-C_{i}\left(P_{i}\right)
$$

Where, $C_{i}\left(P_{i}\right)=e_{i} P_{i}+f_{i} P_{i}^{2} \quad$ is the production cost function of the $i_{\text {supplier, }}^{t h} e_{i}$ and $f_{i}$ are the cost coefficients of the $i^{\text {th }}$ supplier. The objective is to determine $a_{i \text { and }} b_{i}$ so as to maximize $F\left(a_{i}, b_{i}\right)_{\text {,subject to the }}$ constraints (1) to (7). Similarly the consumers have the revenue function; the maximization of the objective for building a bidding strategy can be described by the following equation.

$$
\begin{gathered}
\operatorname{Max} B=B\left(c_{j}, d_{j}\right)=B_{j}\left(L_{j}\right)-R_{j} L_{j} \\
\text { Where, } B_{j}\left(L_{j}\right)=g_{j} L_{j}-h_{j} L_{j}{ }^{2} \text { is the }
\end{gathered}
$$

demand function of the $j^{t h}$ large consumer, $g_{j}$ and $h_{j}$ are the demand coefficients of the $j^{\text {th }}$ large consumer. The objective is to determine $c_{j}$ and $d_{j}$ so as to maximize

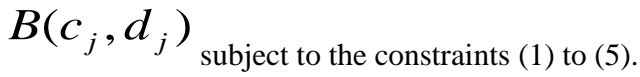

The maximization of the Profit should provide the optimum bidding strategy of the power system.

\section{FORMATION OF THE PROPOSED HYBRID METHOD}

The proposed hybrid method is the combination of the $\mathrm{ABC}$ algorithm and the PSO method. This technique is used for the determination of the best values; it could be a optimal value. Here the $\mathrm{ABC}$ algorithm is used to determine the best values of the system; in this the third stage of the $\mathrm{ABC}$ is replaced by using the PSO method. The proposed method is implemented in two ways, i.e., demand prediction and the optimum bidding strategy determination. The first stage of the proposed method predict the demands of the system by using Neural Network $(\mathrm{NN})$, thereby it aligns with the historical data i.e., the previous days demand. Then it produces the demand of the system. Later the next step is the determination of the best objective function of the system using the $\mathrm{ABC}$ and the PSO method. The proposed method demand prediction is given in the following section 


\subsection{Demand Prediction using Nn}

Using Artificial Neural network has predicted the demand in the first stage of the proposed method. The NN consists of three layers like, input layer, hidden layer and output layer, which is aligned with the previous historical datasets. Here, we are training the ANN using the target power demand with the corresponding input time intervals of a day, i.e., IEX (Indian Energy Exchange) daily demand dataset is given in Appendix. The back propagation algorithm is utilized for the training process. Once the neural network training process is completed, the network is trained well for identifying power demand according to the input time interval. Based on the output of the network, the ABC_PSO algorithm optimizes the bidding strategy. The optimization of bidding strategy using the ABC_PSO algorithm is explained in the following section

\subsection{Optimum Bidding Strategy Determination Using Hybrid Technique}

Hybrid technique is the combination of the $\mathrm{ABC}$ algorithm and the PSO technique. The ABC algorithm is used in the best objective function solutions; the final stage of the $\mathrm{ABC}$ algorithm uses the PSO technique. Artificial Bee Colony $(\mathrm{ABC})$ is one of the most recently defined algorithms by Dervish Karaboga in 2005, motivated by the intelligent behavior of honey bees. It is as simple as Particle Swarm Optimization (PSO) and Differential Evolution (DE) algorithms, and uses only common control parameters such as colony size and maximum cycle number. The $\mathrm{ABC}$ algorithm mainly considers the three processes of bees, like employee bee, onlooker bee and scout bee. The employee bee is searching best values of the given process, onlooker bee checks the conditions that produce the solutions for the process and finally if the results do not satisfy the constraints, it could be given to the scout bee. It is an optional process, if the second process doesn't satisfy the limits that are used to produce random solutions of the given process.

The proposed hybrid technique PSO is used as the random solution generation. The particle swarm optimization (PSO) algorithm was first presented by Dr. Kennedy and Dr. Eberhart, and is a random evolution method based on intelligent search of the group birds. It has quick convergence speed and optimal searching ability for solving large-scale optimization problems. Here it is used for the scout bee stage of the $\mathrm{ABC}$ algorithm and it is used to find the random generation of optimum objective function values. This value is used for the onlooker bee iterations. The procedure for the $\mathrm{ABC}$ algorithm and the PSO is given in the following section.

\subsection{Procedure}

Step 1: Initialize the population of the generating unit's solutions $M_{i, j}$

Step 2: Evaluate the populations using the employee bee; it could select the best value for the next iteration. It is the best value, that satisfies the maximized objective function value, which is given by,

$$
\operatorname{Max} F=F\left(a_{i}, b_{i}\right)=R P_{i}-C_{i}\left(P_{i}\right)
$$

Step 3: The best objective function values are denoted by $E_{i, j}$

Step 4: Set the iteration count is one, i.e., cycle $=1$.
Step 5: Produce the new solutions for the problem (food positions) in the onlooker bee.

$$
V_{i, j}=m_{i, j}+\Phi_{i . j}\left(m_{i, j}-m_{k, j}\right)
$$

Where, $\mathrm{k}$ is the solution the neighborhood of $\mathrm{i}$ and $\Phi$ is a random number in the range $[-1,1], V_{i, j}$ is the neighborhood solution of $M_{i, j}$.

Step 6: Apply the objective function for the new food positions or the new solutions, the selected best value depends on the following conditions.

If the neighborhood solution $E_{i, j}$ is greater or most fit value compare to the initial $M_{i, j}$ value means, it has replaced the best objective function value.

If the neighborhood solution $E_{i, j}$ is not a fitt value

compared to the $M_{i, j}$ value means, it is to be replaced with the best objective value.

The best objective function values are not satisfied for the constraints means go to the next step.

Step 7: The scout bee has used the PSO technique, which generates the random solutions and it fixed the initial velocity is zero.

Step 8: Initialize the populations of the modified solutions $E_{i, j}$

Step 9: Generate the random solutions, i.e., update the particle positions using the following equation.

$V_{i d}{ }^{k+1}=w V_{i d}{ }^{k}+C_{1}$ rand $^{*}\left(\right.$ Pbest $\left._{i d}-S_{i d}{ }^{k}\right)+C_{2} \operatorname{rand}^{*}\left(\right.$ Gbest $\left._{i d}-S_{i d}{ }^{k}\right)$

Current position can be modified by

$S_{i d}{ }^{k}=S_{i d}{ }^{k}+V_{i d}{ }^{k+1}, i=1,2, \ldots n$ and $d=1,2, \ldots m$.

Where, $S^{k}$ is the current searching point, $S^{k+1}$ is modified searching point, $V^{k}$ is the current velocity, $V^{k+1}$ is modified velocity, $n$ is the number of particles in a group, $m$ is the number of members in a group, ${ }^{w_{i}}$ is the weight function for the velocity of the agent $i$. The weight function is given in the equation.

$w_{i}=w_{\max }-\frac{w_{\max }-w_{\min }}{F_{\max }} * F$

Step 10: Then the value is given to the step 2, the process continues until the maximized value obtained.

Once the process has completed, the network is ready to produce the optimum bidding strategy of the system. The 
performance of the all the three methods, the $\mathrm{ABC}$ technique and PSO are analyzed using the MATLAB platform. The corresponding results are tabulated and the graphical representation of the proposed system is given below.

\section{EXPERIMENTAL RESULTS AND DISCUSSIONS}

Table.1: Implementation parameters

\begin{tabular}{|c|c|c|c|c|c|}
\hline \multirow{2}{*}{$\begin{array}{l}\text { Gener } \\
\text { ators }\end{array}$} & \multicolumn{2}{|c|}{ Generation limits } & \multicolumn{3}{|c|}{ Cost coefficients } \\
\hline & $\begin{array}{l}\text { Mini } \\
\text { mum }\end{array}$ & $\begin{array}{l}\text { Maximu } \\
\mathrm{m}\end{array}$ & $a_{i}$ & $b_{i}$ & $c_{i}$ \\
\hline G1 & 50 & 200 & 0 & 2.00 & 0.003 \\
\hline $\mathrm{G} 2$ & 20 & 80 & 0 & 1.75 & 0.017 \\
\hline G3 & 15 & 50 & 0 & 1.00 & 0.062 \\
\hline G4 & 10 & 35 & 0 & 3.25 & 0.008 \\
\hline G5 & 10 & 30 & 0 & 3.00 & 0.025 \\
\hline G6 & 12 & 40 & 0 & 3.00 & 0.025 \\
\hline
\end{tabular}

The proposed hybrid method was implemented in MATLAB platform, mainly to increase the profit of the sellers, while satisfying the demands and also to minimize the associated risks of the system; this can be done by optimal bidding strategy. The demand prediction of the proposed method is done by the NN technique; this could produce the demand of the system using the historical data analysis. The proposed technique is the combination of the $\mathrm{ABC}$ and the PSO technique. The third stage of the $\mathrm{ABC}$ technique uses the PSO method; it is used for the random numbers of solution generation. The optimum bidding for every demand is calculated and the performance of each method is analyzed in this section. The standard IEEE 30 bus system optimum bidding strategy was determined by the various techniques like ABC technique, PSO method and the proposed methods are given in the following tables. The standard IEEE 30 bus system is given in the Appendix-1.

The figure in the Appendix illustrates tested IEEE 30 bus system structure, this system consists of six generators. The Forecasted Load evaluations for ABC technique, PSO method and Hybrid method is given in the following tables 2, 3, 4, 5, 6 and 7.

Table.2: Optimum bidding parameters with Profit using ABC

\begin{tabular}{|c|c|c|c|c|c|c|c|c|c|}
\hline \multirow{2}{*}{$\begin{array}{l}\text { Ti } \\
\text { me } \\
\text { in } \\
\text { hou } \\
\text { rs }\end{array}$} & \multicolumn{6}{|c|}{ Generators values in $\mathrm{MW}$} & \multirow{2}{*}{$\begin{array}{c}\text { Loa } \\
\mathrm{d} \\
\text { dem } \\
\text { and } \\
\text { in } \\
\text { M } \\
\text { W }\end{array}$} & \multirow[b]{2}{*}{$\begin{array}{c}\text { Prof } \\
\text { it }\end{array}$} & \multirow{2}{*}{$\begin{array}{l}\mathrm{M} \\
\mathrm{C} \\
\mathrm{P}\end{array}$} \\
\hline & G1 & $\begin{array}{l}\mathrm{G} \\
2\end{array}$ & $\begin{array}{l}G \\
3\end{array}$ & $\begin{array}{l}\mathrm{G} \\
4\end{array}$ & $\begin{array}{l}\mathrm{G} \\
5\end{array}$ & $\begin{array}{l}G \\
6\end{array}$ & & & \\
\hline 0.3 & $\begin{array}{c}10 \\
4\end{array}$ & 47 & 41 & 33 & $\begin{array}{l}2 \\
2\end{array}$ & 22 & $\begin{array}{c}295 . \\
34\end{array}$ & $\begin{array}{c}539 \\
.60 \\
8\end{array}$ & $\begin{array}{l}7 \\
6 \\
6 \\
2 \\
8\end{array}$ \\
\hline 5.3 & $\begin{array}{c}10 \\
1\end{array}$ & 76 & 30 & 18 & $\begin{array}{l}2 \\
6\end{array}$ & 26 & $\begin{array}{c}278 . \\
95\end{array}$ & $\begin{array}{r}599 \\
.55\end{array}$ & 7 \\
\hline
\end{tabular}

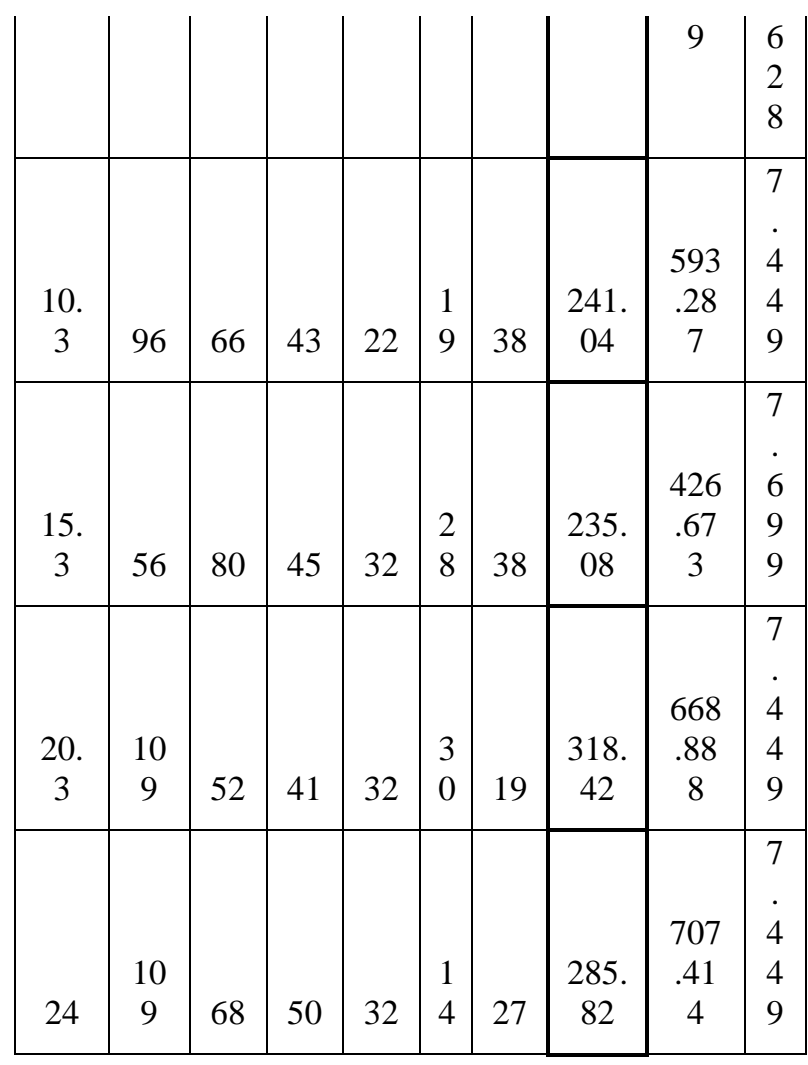

Table.3: Optimum bidding parameters with Profit using PSO

\begin{tabular}{|c|c|c|c|c|c|c|c|c|c|}
\hline \multirow{2}{*}{$\begin{array}{l}\mathrm{Ti} \\
\text { me } \\
\text { in } \\
\text { ho } \\
\text { urs }\end{array}$} & \multicolumn{6}{|c|}{ Generators values in MW } & \multirow{2}{*}{$\begin{array}{c}\text { Loa } \\
\mathrm{d} \\
\text { dem } \\
\text { and } \\
\text { in } \\
\mathrm{M} \\
\mathrm{W}\end{array}$} & \multirow{2}{*}{$\begin{array}{l}\text { Pr } \\
\text { of } \\
\text { it }\end{array}$} & \multirow{2}{*}{$\begin{array}{l}\mathrm{M} \\
\mathrm{C} \\
\mathrm{P}\end{array}$} \\
\hline & G & C) & G & G & G5 & G & & & \\
\hline 0.3 & $\begin{array}{c}10 \\
2\end{array}$ & $\begin{array}{c}65 . \\
5\end{array}$ & 35 & 33 & $\begin{array}{c}25.7 \\
5\end{array}$ & 28 & $\begin{array}{l}295 \\
.34\end{array}$ & $\begin{array}{l}5 \\
6 \\
8 . \\
1 \\
1\end{array}$ & $\begin{array}{l}7 \\
8 \\
8 \\
3 \\
8\end{array}$ \\
\hline 5.3 & 50 & 30 & 27 & 13 & 26 & 12 & $\begin{array}{r}278 \\
.95\end{array}$ & $\begin{array}{l}1 \\
5 \\
5 . \\
5 \\
0\end{array}$ & $\begin{array}{l}7 \\
9 \\
9 \\
7 \\
8\end{array}$ \\
\hline $\begin{array}{c}10 . \\
3\end{array}$ & 54 & 42 & 32 & 20 & 14 & 13 & $\begin{array}{c}241 \\
.04 \\
7\end{array}$ & $\begin{array}{l}2 \\
2 \\
0 . \\
0 \\
6\end{array}$ & $\begin{array}{l}7 \\
9 \\
9 \\
7 \\
8\end{array}$ \\
\hline $\begin{array}{c}15 . \\
3\end{array}$ & 87 & 79 & 38 & 21 & 23 & 39 & $\begin{array}{r}235 \\
.08\end{array}$ & $\begin{array}{l}5 \\
5 \\
5 . \\
8 \\
6\end{array}$ & $\begin{array}{l}7 \\
6 \\
6 \\
2 \\
8\end{array}$ \\
\hline
\end{tabular}




\begin{tabular}{|c|c|c|c|c|c|c|c|c|c|}
\hline $\begin{array}{c}20 . \\
3\end{array}$ & 97 & 78 & 34 & 25 & 23 & 25 & $\begin{array}{c}318 \\
.42\end{array}$ & $\begin{array}{l}5 \\
8 \\
5 . \\
6 \\
1\end{array}$ & $\begin{array}{l}7 \\
. \\
6 \\
2 \\
8\end{array}$ \\
\hline 24 & $\begin{array}{c}13 \\
0\end{array}$ & 74 & 50 & 17 & 17 & 28 & $\begin{array}{r}285 \\
.82\end{array}$ & $\begin{array}{l}8 \\
5 \\
6 . \\
2 \\
8\end{array}$ & $\begin{array}{l}7 \\
. \\
6 \\
2 \\
8\end{array}$ \\
\hline
\end{tabular}

Table.4: Optimum bidding parameters with Profit using ABC PSO

\begin{tabular}{|c|c|c|c|c|c|c|c|c|c|}
\hline \multirow{2}{*}{$\begin{array}{c}\text { Tim } \\
\mathrm{e} \\
\text { in } \\
\text { hour } \\
\mathrm{s}\end{array}$} & \multicolumn{6}{|c|}{$\begin{array}{c}\text { Generators values in } \\
\text { MW }\end{array}$} & \multirow{2}{*}{$\begin{array}{c}\text { Loa } \\
\text { d } \\
\text { dem } \\
\text { and } \\
\text { in } \\
\text { MW }\end{array}$} & \multirow[b]{2}{*}{$\begin{array}{c}\text { Prof } \\
\text { it }\end{array}$} & \multirow[b]{2}{*}{$\mathrm{MCP}$} \\
\hline & $\begin{array}{l}\mathrm{G} \\
1\end{array}$ & $\begin{array}{l}G \\
2\end{array}$ & $\begin{array}{l}\mathrm{G} \\
3\end{array}$ & $\begin{array}{l}\text { G } \\
4\end{array}$ & $\begin{array}{l}\mathrm{G} \\
5\end{array}$ & $\begin{array}{l}G \\
6\end{array}$ & & & \\
\hline 0.3 & $\begin{array}{l}9 \\
6\end{array}$ & $\begin{array}{l}4 \\
9\end{array}$ & 40 & 30 & $\begin{array}{l}1 \\
3\end{array}$ & 39 & $\begin{array}{c}295 . \\
34\end{array}$ & $\begin{array}{l}487 . \\
996\end{array}$ & 7.69 \\
\hline 5.3 & $\begin{array}{l}1 \\
1 \\
1\end{array}$ & $\begin{array}{l}6 \\
1\end{array}$ & 50 & 23 & $\begin{array}{l}2 \\
2\end{array}$ & 25 & $\begin{array}{c}278 . \\
95\end{array}$ & $\begin{array}{l}594 . \\
855\end{array}$ & 7.69 \\
\hline 10.3 & $\begin{array}{l}1 \\
1 \\
9\end{array}$ & $\begin{array}{l}6 \\
4\end{array}$ & 30 & 14 & $\begin{array}{l}1 \\
6\end{array}$ & 39 & $\begin{array}{c}241 . \\
047\end{array}$ & $\begin{array}{c}709 . \\
719\end{array}$ & 7.69 \\
\hline 15.3 & $\begin{array}{l}1 \\
3 \\
5\end{array}$ & $\begin{array}{l}4 \\
5\end{array}$ & 27 & 19 & $\begin{array}{l}2 \\
2\end{array}$ & 33 & $\begin{array}{c}235 . \\
08\end{array}$ & $\begin{array}{l}917 . \\
291\end{array}$ & 7.44 \\
\hline 20.3 & $\begin{array}{l}1 \\
1 \\
5\end{array}$ & $\begin{array}{l}8 \\
0\end{array}$ & 48 & 20 & $\begin{array}{l}1 \\
6\end{array}$ & 35 & $\begin{array}{c}318 . \\
42\end{array}$ & $\begin{array}{l}740 . \\
553\end{array}$ & 7.69 \\
\hline 24 & $\begin{array}{l}1 \\
3 \\
4\end{array}$ & $\begin{array}{l}6 \\
0\end{array}$ & 48 & 27 & $\begin{array}{l}2 \\
8\end{array}$ & 13 & $\begin{array}{c}285 . \\
82\end{array}$ & $\begin{array}{l}849 . \\
528\end{array}$ & 7.69 \\
\hline
\end{tabular}

Table.5: Optimum bidding parameters with Fuel cost using ABC

\begin{tabular}{|c|c|c|c|c|c|c|c|c|c|}
\hline \multirow{2}{*}{$\begin{array}{l}\mathrm{Ti} \\
\text { me } \\
\text { in } \\
\text { hou } \\
\text { rs }\end{array}$} & \multicolumn{6}{|c|}{ Generators values in MW } & \multirow{2}{*}{ 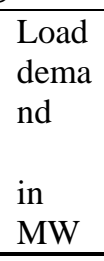 } & \multirow{2}{*}{$\begin{array}{l}\text { Fue } \\
1 \\
\text { cost } \\
\$ / \mathrm{hr}\end{array}$} & \multirow[b]{2}{*}{$\begin{array}{c}\mathrm{MC} \\
\mathrm{C}\end{array}$} \\
\hline & G & G & G & G & G & G & & & \\
\hline 03 & 10 & 4 & 4 & 3 & 2 & 2 & $\begin{array}{c}295.3 \\
4\end{array}$ & $\begin{array}{l}45 . \\
79\end{array}$ & 7.6 \\
\hline 0.3 & 10 & 7 & 3 & 3 & 2 & 2 & 278.9 & & 7.6 \\
\hline 5.3 & 1 & 6 & 0 & 8 & 6 & 6 & 5 & 17 & 28 \\
\hline
\end{tabular}

\begin{tabular}{|c|c|c|c|c|c|c|c|c|c|}
10. & & 6 & 4 & 2 & 1 & 3 & 241.0 & 41. & 7.4 \\
3 & 96 & 6 & 3 & 2 & 9 & 8 & 4 & 56 & 49 \\
\hline 15. & & 8 & 4 & 3 & 2 & 3 & 235.0 & 97. & 7.6 \\
3 & 56 & 0 & 5 & 2 & 8 & 8 & 8 & 5 & 99 \\
\hline 20. & 10 & 5 & 4 & 3 & 3 & 1 & 318.4 & 66. & 7.4 \\
3 & 9 & 2 & 1 & 2 & 0 & 9 & 2 & 02 & 49 \\
\hline & 10 & 6 & 5 & 3 & 1 & 2 & 285.8 & 46. & 7.4 \\
24 & 9 & 8 & 0 & 2 & 4 & 7 & 2 & 9 & 49 \\
\hline
\end{tabular}

Table.6: Optimum bidding parameters with Fuel cost using PSO

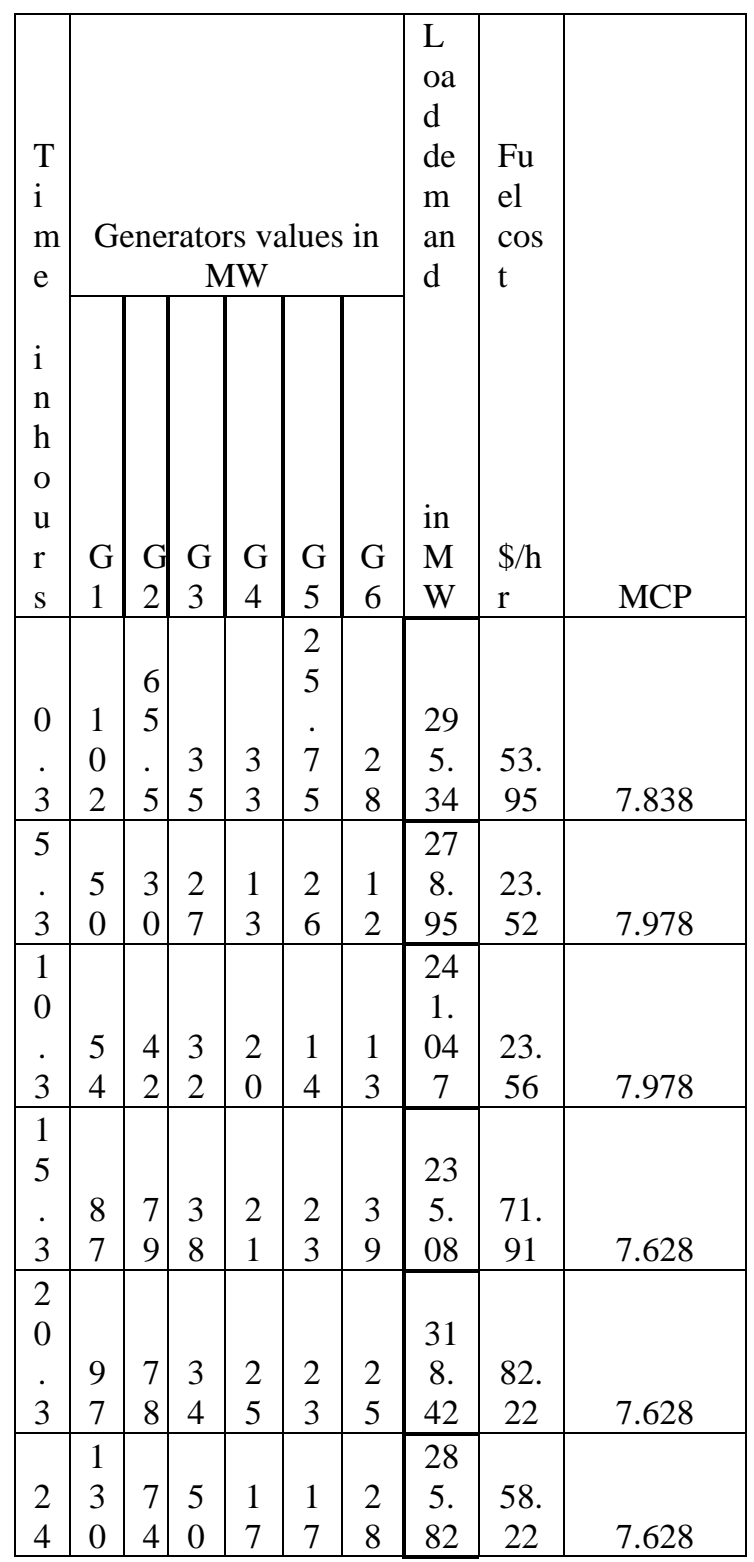


Table.7: Optimum bidding parameters with Fuel cost using ABC_PSO

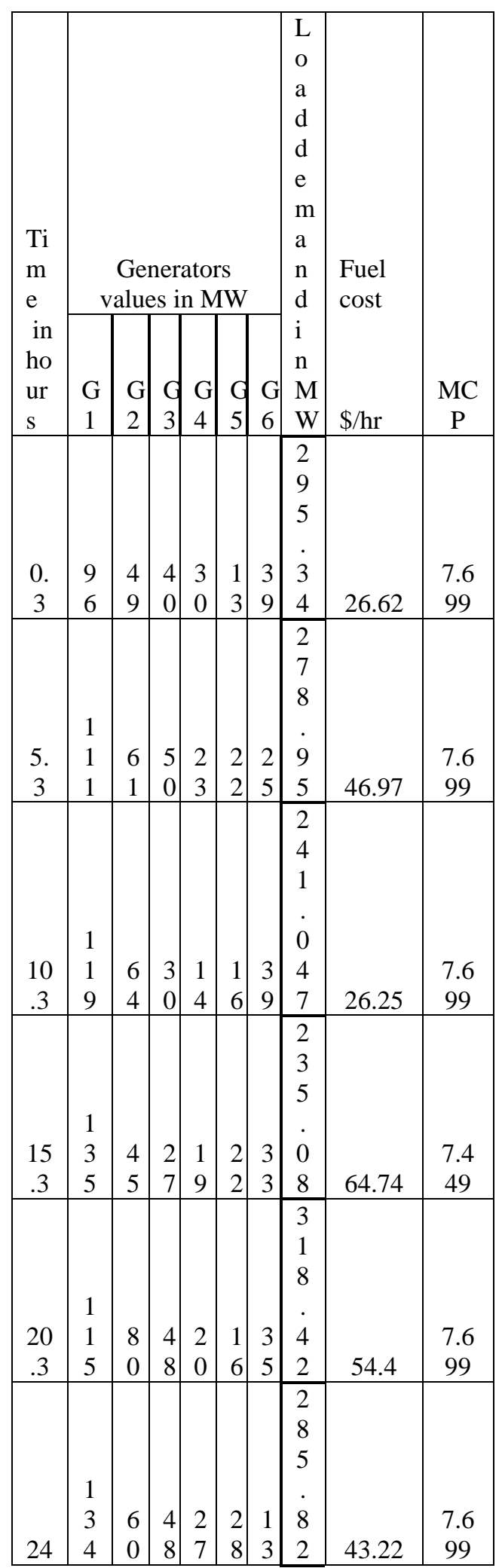

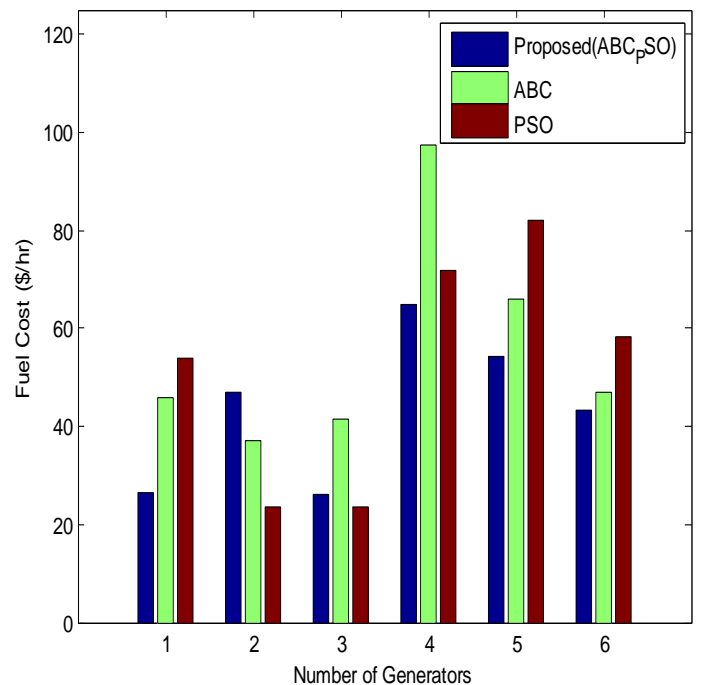

Fig 1: Fuel cost comparison using differentapproaches

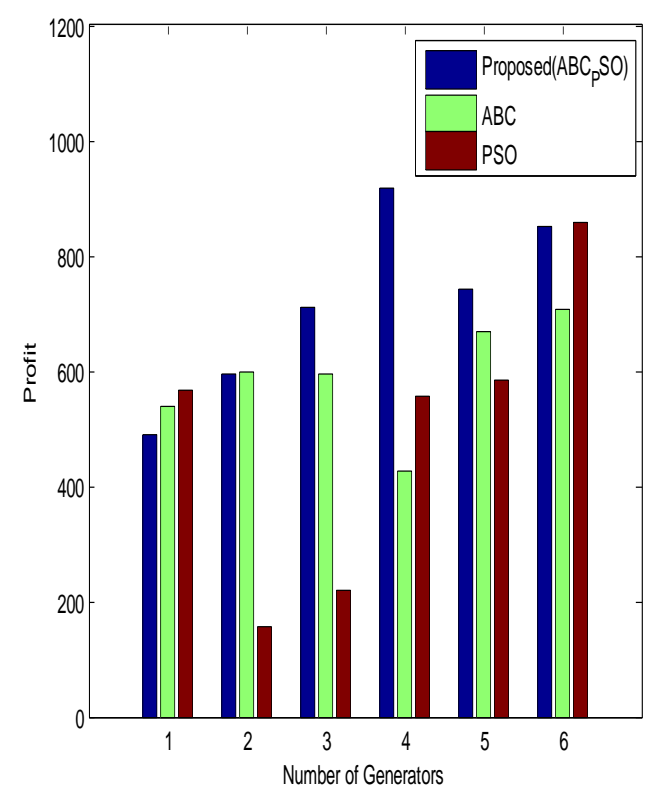

Fig 2: Profit comparison using different approaches

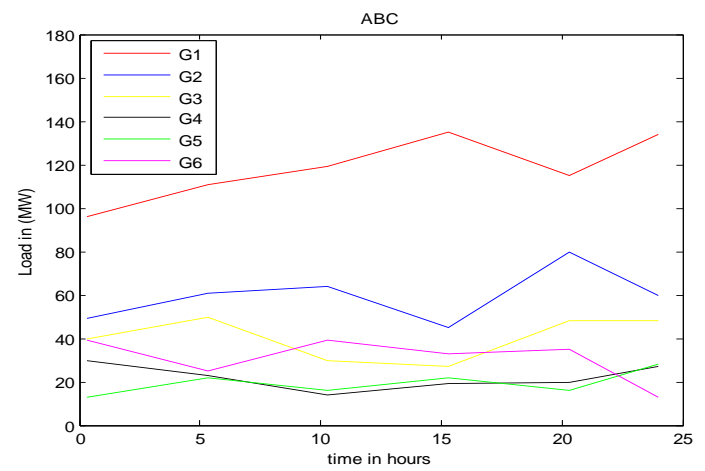

Fig 3: Load combination in $\mathrm{ABC}$ 


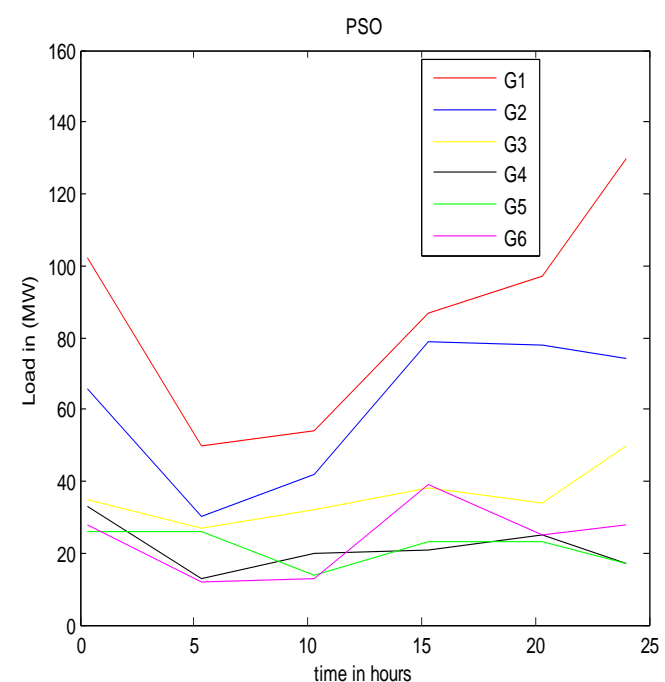

Fig 4: Load combination in PSO

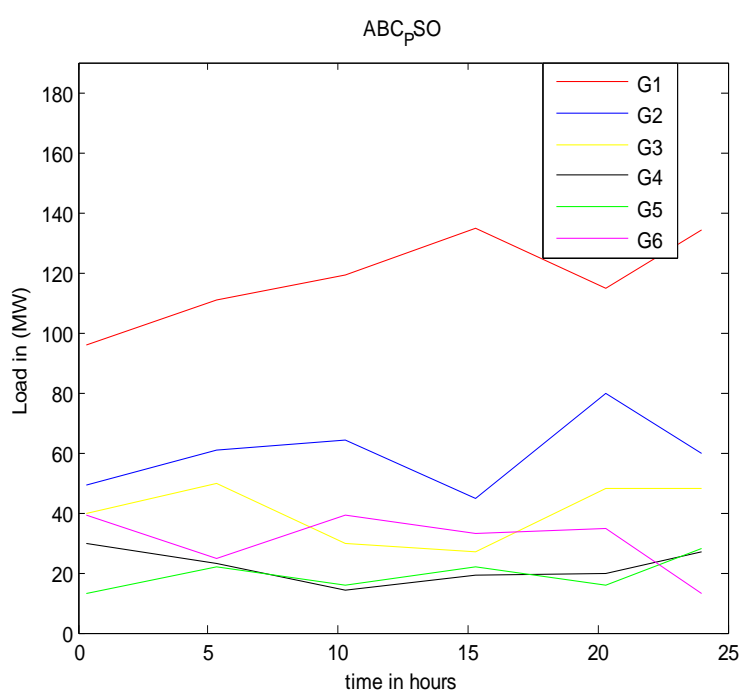

Fig 5: Load combination in Proposed (ABC_PSO)

method

\section{CONCLUSION}

The development of optimal bidding strategies using the new aggregated demand model and the hybrid technique was discussed in this paper. Here the proposed method is used to maximize the profit of the suppliers, while satisfying the demand and to minimize the associated risks of the system. The hybrid model of the proposed system is the combination of the ABC algorithm and the PSO technique. It consists of employee bee, onlooker bee and scout bee. The final stage of the ABC algorithm i.e., scout bee, uses the PSO technique, which produces the random number of solutions of the problem. The output of the proposed system is the maximized Profit values. In this paper we have also analyzed the optimal bidding strategy output of the other techniques like $\mathrm{ABC}$ technique and PSO method separately. These three techniques for Profit results were tabulated as shown in Table.2, 3 and 4 and compared with the help of Graphs shown in Fig.2, and also Fuel cost comparison shown in Fig.1. The comparative results proved that the proposed technique contains the maximized Profit and minimum Fuel cost values which are competent over the other techniques.
6. REFERENCES

[1] D. L. Post, S. S. Coppinger, and G. B. Sheblé, "Application of auctions as a pricing mechanism for the interchange of electric power," IEEE Trans. Power Syst., vol. 10, pp. 1580-1584, Aug. 1995.

[2] G. B. Sheblé, Computational Auction Mechanisms for Restructured Power Industry Operation. Norwell, MA: Kluwer, 1999.

[3] M. Shahidehpour and M. Marvali, Maintenance Scheduling in Restructured Power Systems. Norwell, MA: Kluwer, 2000.

[4] David, A.K. and Fushuan, "Strategic bidding in competitive electricity markets: a literature survey", IEEE Power Engineering Society Summer Meeting, Seattle, WA, July 16-20, vol. 4, pp. 2168 2173, 2000.

[5] TengshunPeng and Kevin Tomsovic, "Congestion Influence on Bidding Strategiesin an Electricity Market", IEEE Transactions on Power Systems, Vol. 18, No. 3, pp. 1054-1061, 2003.

[6] Gountis, V.P. and Bakirtzis, 'Bidding strategies for electricity producers in a competitive electricity marketplace" IEEE Transactions on Power Systems, Vol.19, No.1 , 356-365, 2004.

[7] J. Vijaya Kumar, D.M. Vinod Kumar, "Particle swarm optimization based optimal bidding strategy in an open Electricity market", International Journal of Engineering, Science and Technology Vol. 3, No. 6, , pp. 283-294, 2011.

[8] Reinhard Haas, Christian Panzer, Gustav Resch , Mario Ragwitz, Gemma Reece and Anne Held, "A historical review of promotion strategies for electricity from renewable energy sources in EU countries", Elsevier in its journal Renewable and Sustainable Energy Reviews,Vol. 15, No. 2, pp.1003-1034, 2011.

[9] J.Vijaya Kumar, D.M.Vinod Kumar and K.Edukondalu, "Strategic bidding using fuzzy adaptive gravitational search algorithm in a pool based electricity market", Applied Soft Computing, Vol.13, No.5, pp.2445-2455, 2013.

[10] Dervis Karaboga and Bahriye Basturk, "Artificial Bee Colony (ABC) Optimization Algorithm for Solving Constrained Optimization Problems", World Congress on Foundations of Fuzzy Logic and Soft Computing, pp.789-798, 2007.

[11] Indian Electricity Exchange [Online]: Available: www.iexindia.com

\section{AUTHOR PROFILE}

V.Madhu Sudana Reddy received his B.Tech in Electrical and Electronics Engineering from S.V.U.C.E. Tirupathi in 2003, and his M.E. from Sathyabama University Chennai in 2006. $\mathrm{He}$ is currently pursuing $\mathrm{PhD}$ from J.N.T.U.H. Hyderabad and also working as Associate Professor in Visvodaya Engineering College, Kavali. He is life member of I.S.T.E., his current research include Power System Deregulation and application of AI techniques in Power Systems.

Dr.B.Subramanyam received his B.E. in Electrical and Electronics Engineering from S.V.U.C.E. Tirupathi in 1968, 
his M.E. from N.I.T. Warangal in 1971, and his Ph.D from N.I.T. Warangal, India in 1977 , He has been worked as Dean, Faculty of Engineering in S.V.U.C.E. Tirupathi, he is currently working as Professor in P.B.R.Visvodaya Institute of Technology and Science, Kavali. His current research interest includes Automation of Distribution Systems, Reliability of Systems and Studies on different types of instrumentation systems in a space organization.

Dr.M.SurayaKalavathi recieved her B.E in Electrical and Electronics Engineering from S.V.U.C.E., Tirupathi in 1988, M.E from S.V.U.C.E., Tirupathi in 1993 and Ph.D from JNT University Hyderabad, India. She is Professor of Electrical and Electronics Engineering at J.N.T.U.H,Hyderabad. Her current research interests includes Fault diagnosis in Transformer, AI techniques in Power system.

\section{APPENDIX}

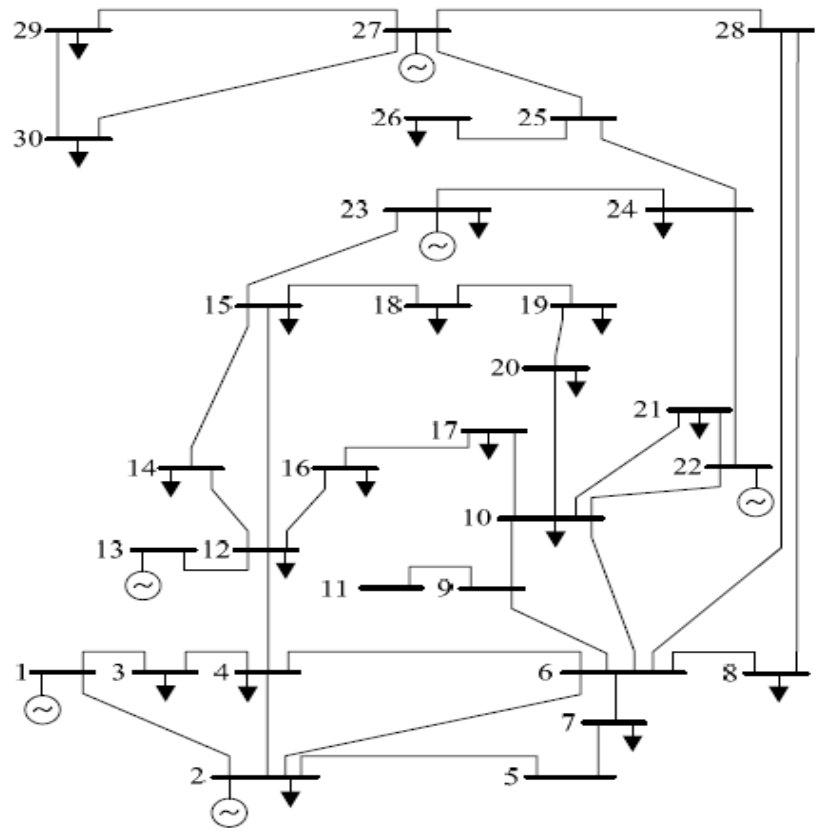

Fig: Structure of the IEEE 30 bus system

Table: IEX data

\begin{tabular}{|c|c|c|c|}
\hline $\begin{array}{c}\text { Date } \begin{array}{c}\text { Hour | Time } \\
\text { Block }\end{array} \\
\text { 06-03-2014 }\end{array}$ & S1 & \\
\hline \multirow{5}{*}{1} & $\begin{array}{c}00: 00- \\
00: 15\end{array}$ & 295.37 & 145.40 \\
\cline { 2 - 4 } & $\begin{array}{c}00: 15- \\
00: 30\end{array}$ & 295.37 & 145.40 \\
\cline { 2 - 4 } & $\begin{array}{c}00: 30- \\
00: 45\end{array}$ & 295.37 & 145.40 \\
\cline { 2 - 4 } & $\begin{array}{c}00: 45- \\
01: 00\end{array}$ & 295.37 & 145.40 \\
\hline \multirow{5}{*}{2} & $\begin{array}{c}01: 00- \\
01: 15\end{array}$ & 295.37 & 145.40 \\
\cline { 2 - 4 } & $01: 15-$ & 295.37 & 145.40 \\
& $01: 30$ & & \\
\hline
\end{tabular}

\begin{tabular}{|c|c|c|c|}
\hline & $\begin{array}{c}01: 30- \\
01: 45\end{array}$ & 295.37 & 145.40 \\
\hline & $\begin{array}{c}01: 45- \\
02: 00\end{array}$ & 295.37 & 145.40 \\
\hline \multirow{4}{*}{3} & $\begin{array}{c}02: 00- \\
02: 15\end{array}$ & 295.37 & 145.40 \\
\hline & $\begin{array}{c}02: 15- \\
02: 30\end{array}$ & 295.37 & 145.40 \\
\hline & $\begin{array}{c}02: 30- \\
02: 45\end{array}$ & 295.37 & 145.40 \\
\hline & $\begin{array}{c}02: 45- \\
03: 00\end{array}$ & 295.37 & 145.40 \\
\hline \multirow{4}{*}{4} & $\begin{array}{c}03: 00- \\
03: 15\end{array}$ & 295.37 & 145.40 \\
\hline & $\begin{array}{c}03: 15- \\
03: 30\end{array}$ & 295.37 & 145.40 \\
\hline & $\begin{array}{c}03: 30- \\
03: 45\end{array}$ & 295.37 & 145.40 \\
\hline & $\begin{array}{c}03: 45- \\
04: 00\end{array}$ & 295.37 & 145.40 \\
\hline \multirow{4}{*}{5} & $\begin{array}{c}04: 00- \\
04: 15\end{array}$ & 295.37 & 145.40 \\
\hline & $\begin{array}{c}04: 15- \\
04: 30\end{array}$ & 295.37 & 145.40 \\
\hline & $\begin{array}{c}04: 30- \\
04: 45\end{array}$ & 295.37 & 145.40 \\
\hline & $\begin{array}{c}04: 45- \\
05: 00\end{array}$ & 295.37 & 145.40 \\
\hline \multirow{4}{*}{6} & $\begin{array}{c}05: 00- \\
05: 15\end{array}$ & 273.92 & 129.00 \\
\hline & $\begin{array}{c}05: 15- \\
05: 30\end{array}$ & 273.92 & 129.00 \\
\hline & $\begin{array}{c}705: 30- \\
05: 45\end{array}$ & 273.92 & 129.00 \\
\hline & $\begin{array}{c}05: 45- \\
06: 00\end{array}$ & 273.88 & 129.00 \\
\hline \multirow{4}{*}{7} & $\begin{array}{c}06: 00- \\
06: 15\end{array}$ & 232.57 & 132.90 \\
\hline & $\begin{array}{c}06: 15- \\
06: 30\end{array}$ & 232.51 & 132.90 \\
\hline & $\begin{array}{c}06: 30- \\
06: 45\end{array}$ & 232.53 & 132.90 \\
\hline & $\begin{array}{c}06: 45- \\
07: 00\end{array}$ & 232.53 & 132.90 \\
\hline \multirow[t]{2}{*}{8} & $\begin{array}{c}07: 00- \\
07: 15\end{array}$ & 237.69 & 132.90 \\
\hline & $07: 15-$ & 237.69 & 132.90 \\
\hline
\end{tabular}




\begin{tabular}{|c|c|c|c|}
\hline & $07: 30$ & & \\
\hline & $\begin{array}{l}07: 30- \\
07: 45\end{array}$ & 237.69 & 132.90 \\
\hline & $\begin{array}{c}07: 45- \\
08: 00\end{array}$ & 237.69 & 132.90 \\
\hline \multirow{4}{*}{9} & $\begin{array}{l}08: 00- \\
08: 15\end{array}$ & 237.60 & 132.90 \\
\hline & $\begin{array}{c}08: 15- \\
08: 30\end{array}$ & 237.60 & 132.90 \\
\hline & $\begin{array}{c}08: 30- \\
08: 45\end{array}$ & 237.60 & 132.90 \\
\hline & $\begin{array}{c}\text { 08:45 - } \\
09: 00\end{array}$ & 237.60 & 132.90 \\
\hline \multirow{4}{*}{10} & $\begin{array}{c}09: 00- \\
09: 15\end{array}$ & 237.43 & 132.90 \\
\hline & $\begin{array}{c}09: 15- \\
09: 30\end{array}$ & 237.42 & 132.90 \\
\hline & $\begin{array}{c}09: 30- \\
09: 45\end{array}$ & 237.42 & 132.90 \\
\hline & $\begin{array}{c}09: 45- \\
10: 00\end{array}$ & 237.43 & 132.90 \\
\hline \multirow{4}{*}{11} & $\begin{array}{c}10: 00- \\
10: 15\end{array}$ & 241.97 & 137.00 \\
\hline & $\begin{array}{c}10: 15- \\
10: 30\end{array}$ & 241.97 & 137.00 \\
\hline & $\begin{array}{c}10: 30- \\
10: 45\end{array}$ & 241.97 & 137.00 \\
\hline & $\begin{array}{c}10: 45- \\
11: 00\end{array}$ & 241.97 & 137.00 \\
\hline \multirow{4}{*}{12} & $\begin{array}{c}11: 00- \\
11: 15\end{array}$ & 241.97 & 137.00 \\
\hline & $\begin{array}{c}11: 15- \\
11: 30\end{array}$ & 241.97 & 137.00 \\
\hline & $\begin{array}{c}11: 30- \\
11: 45\end{array}$ & 241.97 & 137.00 \\
\hline & $\begin{array}{c}11: 45- \\
12: 00\end{array}$ & 241.97 & 137.00 \\
\hline \multirow{4}{*}{13} & $\begin{array}{c}12: 00- \\
12: 15\end{array}$ & 240.97 & 136.00 \\
\hline & $\begin{array}{c}12: 15- \\
12: 30\end{array}$ & 240.97 & 136.00 \\
\hline & $\begin{array}{c}12: 30- \\
12: 45\end{array}$ & 240.97 & 136.00 \\
\hline & $\begin{array}{c}12: 45- \\
13: 00\end{array}$ & 240.97 & 136.00 \\
\hline 14 & $\begin{array}{c}13: 00- \\
13: 15\end{array}$ & 240.97 & 136.00 \\
\hline
\end{tabular}

\begin{tabular}{|c|c|c|c|}
\hline & $\begin{array}{c}13: 15- \\
13: 30\end{array}$ & 240.97 & 136.00 \\
\hline & $\begin{array}{c}13: 30- \\
13: 45\end{array}$ & 240.97 & 136.00 \\
\hline & $\begin{array}{c}13: 45- \\
14: 00\end{array}$ & 240.97 & 136.00 \\
\hline \multirow{4}{*}{15} & $\begin{array}{c}14: 00- \\
14: 15\end{array}$ & 240.97 & 136.00 \\
\hline & $\begin{array}{c}14: 15- \\
14: 30\end{array}$ & 240.97 & 136.00 \\
\hline & $\begin{array}{c}14: 30- \\
14: 45\end{array}$ & 240.97 & 136.00 \\
\hline & $\begin{array}{c}14: 45- \\
15: 00\end{array}$ & 240.97 & 136.00 \\
\hline \multirow{4}{*}{16} & $\begin{array}{c}15: 00- \\
15: 15\end{array}$ & 240.97 & 136.00 \\
\hline & $\begin{array}{c}15: 15- \\
15: 30\end{array}$ & 240.97 & 136.00 \\
\hline & $\begin{array}{c}15: 30- \\
15: 45\end{array}$ & 240.97 & 136.00 \\
\hline & $\begin{array}{c}15: 45- \\
16: 00\end{array}$ & 240.97 & 136.00 \\
\hline \multirow{4}{*}{17} & $\begin{array}{c}16: 00- \\
16: 15\end{array}$ & 298.17 & 193.20 \\
\hline & $\begin{array}{c}16: 15- \\
16: 30\end{array}$ & 298.17 & 193.20 \\
\hline & $\begin{array}{c}16: 30- \\
16: 45\end{array}$ & 298.17 & 193.20 \\
\hline & $\begin{array}{c}16: 45- \\
17: 00\end{array}$ & 298.17 & 193.20 \\
\hline \multirow{4}{*}{18} & $\begin{array}{c}17: 00- \\
17: 15\end{array}$ & 298.17 & 193.20 \\
\hline & $\begin{array}{c}17: 15- \\
17: 30\end{array}$ & 298.17 & 193.20 \\
\hline & $\begin{array}{c}17: 30- \\
17: 45\end{array}$ & 298.17 & 193.20 \\
\hline & $\begin{array}{c}17: 45- \\
18: 00\end{array}$ & 298.17 & 193.20 \\
\hline \multirow{4}{*}{19} & $\begin{array}{c}18: 00- \\
18: 15\end{array}$ & 303.27 & 198.30 \\
\hline & $\begin{array}{c}18: 15- \\
18: 30\end{array}$ & 303.27 & 198.30 \\
\hline & $\begin{array}{c}18: 30- \\
18: 45\end{array}$ & 303.27 & 198.30 \\
\hline & $\begin{array}{c}18: 45- \\
19: 00\end{array}$ & 303.27 & 198.30 \\
\hline 20 & $19: 00$ - & 263.22 & 192.90 \\
\hline
\end{tabular}




\begin{tabular}{|c|c|c|c|}
\hline & $19: 15$ & & \\
\hline & $\begin{array}{c}19: 15- \\
19: 30\end{array}$ & 266.00 & 192.90 \\
\hline & $\begin{array}{c}19: 30- \\
19: 45\end{array}$ & 266.00 & 192.90 \\
\hline & $\begin{array}{c}\text { 19:45 - } \\
20: 00\end{array}$ & 270.20 & 192.90 \\
\hline \multirow{4}{*}{21} & $\begin{array}{c}20: 00- \\
20: 15\end{array}$ & 319.40 & 189.40 \\
\hline & $\begin{array}{c}20: 15- \\
20: 30\end{array}$ & 319.40 & 189.40 \\
\hline & $\begin{array}{c}20: 30- \\
20: 45\end{array}$ & 336.45 & 189.40 \\
\hline & $\begin{array}{c}20: 45- \\
21: 00\end{array}$ & 336.45 & 189.40 \\
\hline \multirow{4}{*}{22} & $\begin{array}{c}21: 00- \\
21: 15\end{array}$ & 335.19 & 189.40 \\
\hline & $\begin{array}{c}21: 15- \\
21: 30\end{array}$ & 335.19 & 189.40 \\
\hline & $\begin{array}{c}21: 30- \\
21: 45\end{array}$ & 335.14 & 189.40 \\
\hline & $\begin{array}{c}2321: 45- \\
22: 00\end{array}$ & 335.14 & 189.40 \\
\hline \multirow{4}{*}{23} & $\begin{array}{c}22: 00- \\
22: 15\end{array}$ & 304.57 & 154.60 \\
\hline & $\begin{array}{c}22: 15- \\
22: 30\end{array}$ & 304.57 & 154.60 \\
\hline & $\begin{array}{c}22: 30- \\
22: 45\end{array}$ & 304.57 & 154.60 \\
\hline & $\begin{array}{c}22: 45- \\
23: 00\end{array}$ & 304.57 & 154.60 \\
\hline \multirow{4}{*}{24} & $\begin{array}{c}23: 00- \\
23: 15\end{array}$ & 304.57 & 154.60 \\
\hline & $\begin{array}{c}23: 15- \\
23: 30\end{array}$ & 304.57 & 154.60 \\
\hline & $\begin{array}{c}23: 30- \\
23: 45\end{array}$ & 304.57 & 154.60 \\
\hline & $\begin{array}{c}23: 45- \\
24: 00\end{array}$ & 304.57 & 154.60 \\
\hline
\end{tabular}

